\title{
Primary data on the impact from trap magmatism on the hydrogeochemistry of brines in the southwestern part of the Kureyka syncline (Siberian Platform)
}

\author{
Dmitry A. Novikov ${ }^{1,2 *}$, Lyudmila M. Zhitova ${ }^{2,3}$, Fedor F. Dultsev ${ }^{1}$, and Anatoliy V. \\ Chernykh $^{1}$ \\ ${ }^{1}$ Trofimuk Institute of Petroleum Geology and Geophysics SB RAS, Laboratory of Hydrogeology of \\ sedimentary basins of Siberia, Koptyuga ave., 3, Novosibirsk 630090, Russia \\ ${ }^{2}$ Novosibirsk State University, Geological and Geophysical Department, Pirogova str., 1, Novosibirsk \\ 630090, Russia \\ ${ }^{3}$ Sobolev Institute of Geology and Mineralogy SB RAS, Laboratory of isotope-analytical methods, \\ Koptyuga ave., 3, Novosibirsk 630090, Russia
}

\begin{abstract}
The new data on the trap magmatism affecting the hydrogeochemistry of brines in southwestern Kureyka syncline in the west of the ancient Siberian platform are presented. The brines occurring in Paleozoic and Proterozoic deposits have salinity (total dissolved solids) varying broadly: from 30.2 to $469.6 \mathrm{~g} / \mathrm{dm}^{3}$ for $\mathrm{Na} \mathrm{Cl}, \mathrm{Na}-\mathrm{Ca} \mathrm{Cl}, \mathrm{Ca}-\mathrm{Na} \mathrm{Cl}$, $\mathrm{Ca}-\mathrm{Mg} \mathrm{Cl}$ and $\mathrm{Ca} \mathrm{Cl}$ types, among which the mixed types (Ca- $\mathrm{Na} \mathrm{Cl}$ and $\mathrm{Na}-\mathrm{Ca} \mathrm{Cl}$ ) are found prevailing. The activity of intrusive trap magmatism in the contact zone (with a strike length of up to $400 \mathrm{~m}$ ) facilitated the disintegration of organic compounds in the free and water-dissolved form $\left(\mathrm{CH}_{4}, \mathrm{C}_{2} \mathrm{H}_{6}, \mathrm{C}_{3} \mathrm{H}_{8}, \mathrm{iC}_{4} \mathrm{H}_{10}, \mathrm{nC}_{4} \mathrm{H}_{10}, \mathrm{iC}_{5} \mathrm{H}_{12}, \mathrm{nC}_{5} \mathrm{H}_{12}, \mathrm{C}_{6} \mathrm{H}_{14}, \mathrm{I}, \mathrm{B}, \mathrm{NH}_{4}\right)$. The reaction of the intruding traps - brines interaction significantly affected the initial composition of brines, showing a shift towards their saturation with iron, aluminum, silica and other components and thus bearing the evidence of possible salt-induced metal extraction from magmatic melts into an orebearing fluid.
\end{abstract}

\section{Introduction}

The evolution of the hydrogeological structure of the southwestern parts of the Kureyka syncline (west of the Siberian platform) is largely controlled by the unique saturation (up to $50 \%$ ) of the geological section with intrusive bodies (Fig. 1). In almost all of the drilled wells, the zones of contact with trap bodies revealed themselves during drilling (specifically, in the upper part of the sedimentary section) through high-rate loss of fluid during drilling (i.e. lost circulation), at times to the extent of catastrophic levels, or

* Corresponding author: NovikovDA@ipgg.sbras.ru 
occasionally through self-discharge of groundwater and brines. The bodies of traps, by themselves, often partition formations with different reservoir pressures, which suggests their high shielding ability. As such, these phenomena are observed in all sedimentary basins on the ancient platforms, where trap magmatic activity is widely spread (e.g. the Karoo in South Africa, MacArthur basin in Northern Australia, Tarim basin in China and others). The study area is characterized by the presence of strong brines, occurrence of thick salt-bearing deposits, cryogenic strata, traps, and the Riphean-Early Cambrian petroleum complexes. The combination thereof provides certain challenges associated with the assessment of petroleum potential and, specifically, with the geothermal regime. One of the key problems is preservation of hydrocarbons (HC) [1].

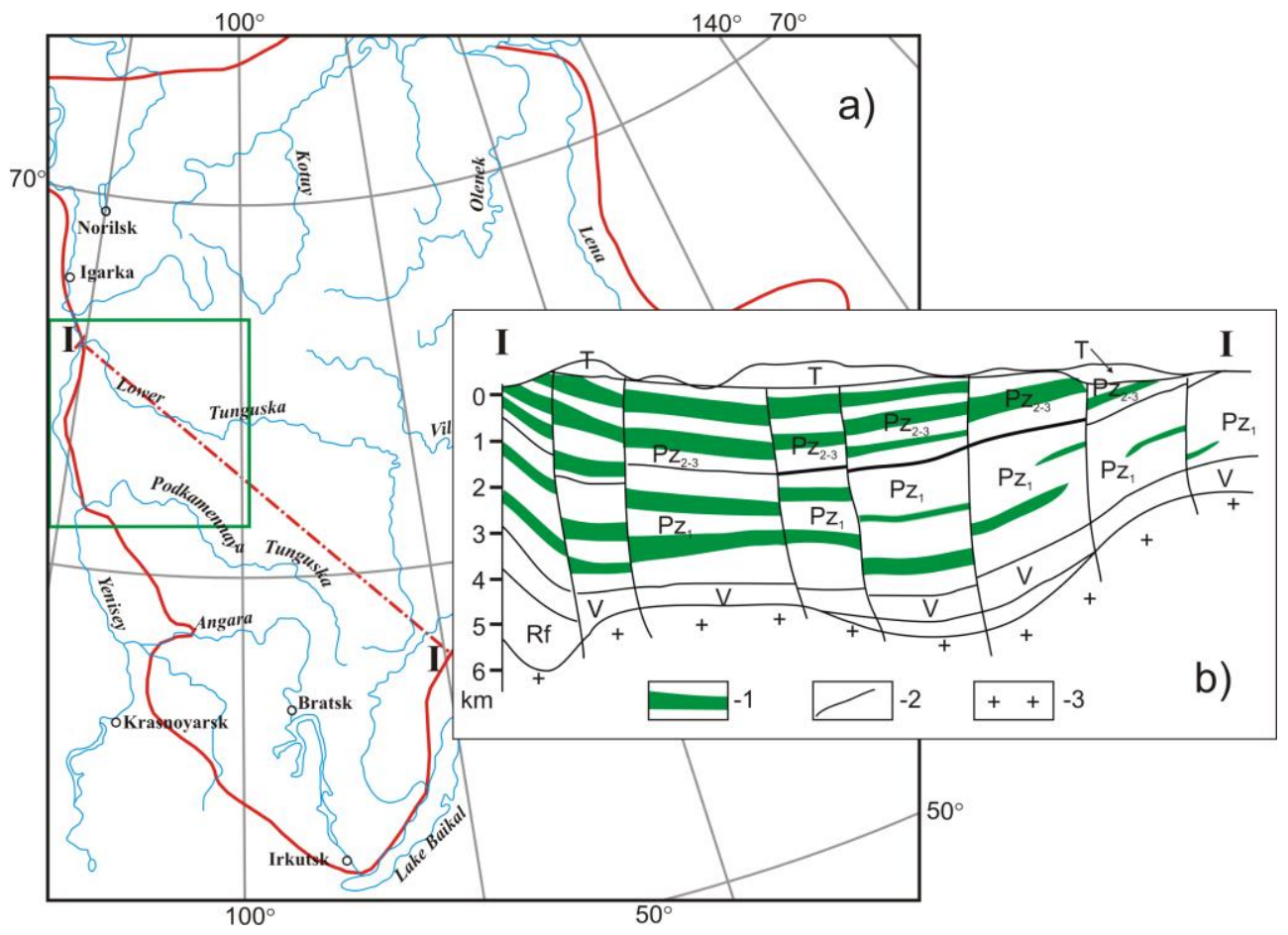

Fig. 1. Study area location map (a) with schematics of sills distribution in the sedimentary cover of the western part of the Siberian platform along the I-I line (b) [1]. Geological section: 1 - sills 2 magma-conducting channels, 3 - the crystalline basement.

The impact of trap magmatism on country rocks of the sedimentary cover within the Siberian platform is observable in different aspects. On the one hand, the Siberian traps intruding within the sediment cover contributed to $\mathrm{CO} / \mathrm{CO}_{2}$ liberation into the atmosphere at levels capable of triggerring catastrophic environmental consequences (greenhouse effect, climate change, mass extinction of living beings), which included burning out of hydrocarbons and graphitization of their host rocks. On the other hand, intrusive trap magmatism favored processes of hydrocarbon maturation in those areas where the sedimentary basin subsidence was not sufficient for the organic matter to achieve thermal maturitation $\left(120-160^{\circ} \mathrm{C}\right)$. In addition, the reaction of the intruding traps interacting with halogenic-carbonate and sulfate deposits of the sedimentary cover resulted in the formation of unique Pt-Cu-Ni, skarn-magnetite accumulations, as well as ore minerals with native iron. 


\section{Results and discussion}

Brines with the total dissolved soilds (TDS) value varying from 30.2 (suprasalt formation) to $469.6 \mathrm{~g} / \mathrm{dm}^{3}$ (salt formation) are found to be widespread in Paleozoic and Proterozoic deposits of the study area. By their chemical composition, the studied brines belong to $\mathrm{Na}$ $\mathrm{Cl}$, Na-Ca-Cl, $\mathrm{Ca}-\mathrm{Cl} \mathrm{Na}-\mathrm{Ca}-\mathrm{Cl}$ and $\mathrm{Ca} \mathrm{Ng} \mathrm{Cl}$ types (after the A.S. Shchukarev' classification), with the dominance of mixed $\mathrm{Ca}-\mathrm{Na}$ and $\mathrm{Cl} \mathrm{Na-Ca-Cl}$ types. Besides, there is a close relationship between the composition and salinity of brines [2-6]. According to their values for total dissolved soilids (TDS), most brines belong either to weakly mineralized $\mathrm{Na} \mathrm{Cl}$ type (TDS $<300 \mathrm{~g} / \mathrm{dm}^{3}$ ), to intermediate $\mathrm{Na}-\mathrm{Ca} \mathrm{Cl}$ and $\mathrm{Ca}-\mathrm{Na} \mathrm{Cl}$ types (TDS $>300 \mathrm{~g} / \mathrm{dm}^{3}$ ), or to $\mathrm{Ca} \mathrm{Cl}$ and $\mathrm{Ca}-\mathrm{Mg} \mathrm{Cl}$ type with the highest salinity (TDS $>400$ $410 \mathrm{~g} / \mathrm{dm}^{3}$ ). The vertical hydrogeochemical zoning is ranked as direct (normal). The TDS values for brines in the suprasalt formation average $310 \mathrm{~g} / \mathrm{dm}^{3}$, in the span from 30.2 to $390.0 \mathrm{~g} / \mathrm{dm}^{3}$. Salinity of brines in the salt formation reaches $469.6 \mathrm{~g} / \mathrm{dm}^{3}$ (on average, 335 $\left.\mathrm{g} / \mathrm{dm}^{3}\right)$. An explicable increase in the amounts of the main salt-forming components is observed with the increasing TDS of brines. Among cations and anions, $\mathrm{Na}^{+}, \mathrm{Ca}^{2+}$ and $\mathrm{Cl}^{-}$ tend to predominate, with their levels reaching $122.2,109.5$ and $287.0 \mathrm{~g} / \mathrm{dm}^{3}$, respectively; other macrocomponents do not exceed the values of 41.3 (for $\mathrm{Mg}^{2+}$ ), 4.7 (for $\mathrm{SO}_{4}{ }^{2-}$ ) and 3.7 $\mathrm{g} / \mathrm{dm}^{3}$ (for $\mathrm{HCO}_{3}$ ). While concentrations vary widely for the following microcomponents: $\mathrm{Br}\left(0.03-6.7 \mathrm{~g} / \mathrm{dm}^{3}\right), \mathrm{B}\left(0.01-790.0 \mathrm{mg} / \mathrm{dm}^{3}\right), \mathrm{I}\left(0.1-53.0 \mathrm{mg} / \mathrm{dm}^{3}\right), \mathrm{SiO}_{2}(2.0-86.0 \mathrm{mg} /$ $\left.\mathrm{dm}^{3}\right), \mathrm{F}\left(1.0-1.5 \mathrm{~g} / \mathrm{dm}^{3}\right)$ and $\mathrm{NH}_{4}\left(0.1-1.9 \mathrm{~g} / \mathrm{m}^{3}\right)$, etc.

We estimated metamorphization degree of brines using the integrated index (S) (after $\mathrm{S}$. L. Shvartsev) [7], generally applicable to such studies for regions exhibiting the presence of brines in their hydrogeological section. Results of the comparative analysis of geochemical characteristics of brines were made the basis for categorizing all the studied brines by their $\mathrm{rNa} / \mathrm{rCl}, \mathrm{Ca} / \mathrm{Cl}$ and $\mathrm{Cl} / \mathrm{Br}$ ratios into three groups, as follows: group 1 which includes brines of $\mathrm{Na} \mathrm{Cl}$ composition, is characterized by the TDS up to $250 \mathrm{~g} / \mathrm{dm}^{3}$ and by enhanced $\mathrm{rNa} / \mathrm{rCl}$ and low $\mathrm{Ca} / \mathrm{Cl}$ ratios, while the integrated index of brines metamorphization degree is usually not more than the value of 165 . Group 2 brackets the brines of transitional Na$\mathrm{Ca}-\mathrm{Cl}$ and $\mathrm{Ca}-\mathrm{Na}$ and $\mathrm{Cl}$ types; these are characterized by TDS between 166 and 405 $\mathrm{g} / \mathrm{dm}^{3}$, their $\mathrm{rNa} / \mathrm{rCl}$ ratio ranges from 0.13 to $0.67 ; \mathrm{Ca} / \mathrm{Cl}$ ratio is from 0.12 to 1.2 , while $\mathrm{S}$ index vary widely from 50 to 350 . The last group (3), which is meant to deal with the highest degree of metamorphization, should include strong brines of $\mathrm{Ca} \mathrm{Cl}$ and $\mathrm{Ca}-\mathrm{Mg} \mathrm{Cl}$ compositions, with TDS values exceeeding $410 \mathrm{~g} / \mathrm{dm}^{3}$; they are marked by low $\mathrm{rNa} / \mathrm{rCl}$ $(<0.24)$ and $\mathrm{Cl} / \mathrm{Br}(<50)$ ratios, while the $\mathrm{Ca} / \mathrm{Cl}$ ratio values are enhanced $(>0.35)$; their $\mathrm{S}$ index values are the highest (reaching the value of 457). The metamorphization degree (catagenetic alterations) of the chemical composition of brines in the study region thus increases from the least mineralized $\mathrm{Na} \mathrm{Cl}$ waters to strong brines rich in $\mathrm{Ca} \mathrm{Cl}$ and $\mathrm{Ca}-\mathrm{Mg}$ $\mathrm{Cl}$. At the earliest stage, fresh waters from the suprasalt formation are of $\mathrm{Na}-\mathrm{Cl} \mathrm{Ca}-\mathrm{HCO}_{3}$ composition and have a salinity of less than $0.5 \mathrm{~g} / \mathrm{dm}^{3}$. The analyzed interplay of the $\mathrm{rNa} / \mathrm{rCl}, \mathrm{Ca} / \mathrm{Cl}, \mathrm{Br} / \mathrm{Cl} * 10-3$ and other ratios, together with the integrated S-index, confirmed the correctness of the inferences made.

The geothermal regime in the subsurface, hydrogeological conditions and hydrogeochemistry of brines both in the study area and across the entire Siberian platform, are found to have been largely influenced throughout the entire time-frame of the intrusions' emplacement. Their patterns is best expressed in the metamorphism of the water-dissolved gas (WDG) composition: if in the intrusion affected zone (within 100 meters), the composition of WDG is dominated by carbon dioxide (more than $90 \mathrm{vol}$. \%) at methane content $<5$ vol. \%, then $\mathrm{CO}_{2}$ levels at a distance of 250 meters are reported to be already as low as 30 vol. $\%$, whereas $\mathrm{CH}_{4}$ concentrations have grown up to $60-70$ vol. $\%$ (Fig. 2a). Similar trends are observed for the whole homologue series from ethane to 
hexane (Fig. 2b). The effect of an intrusive body on the metamorphism of the WDG composition becomes leveled off at a distance of about 400 meters.
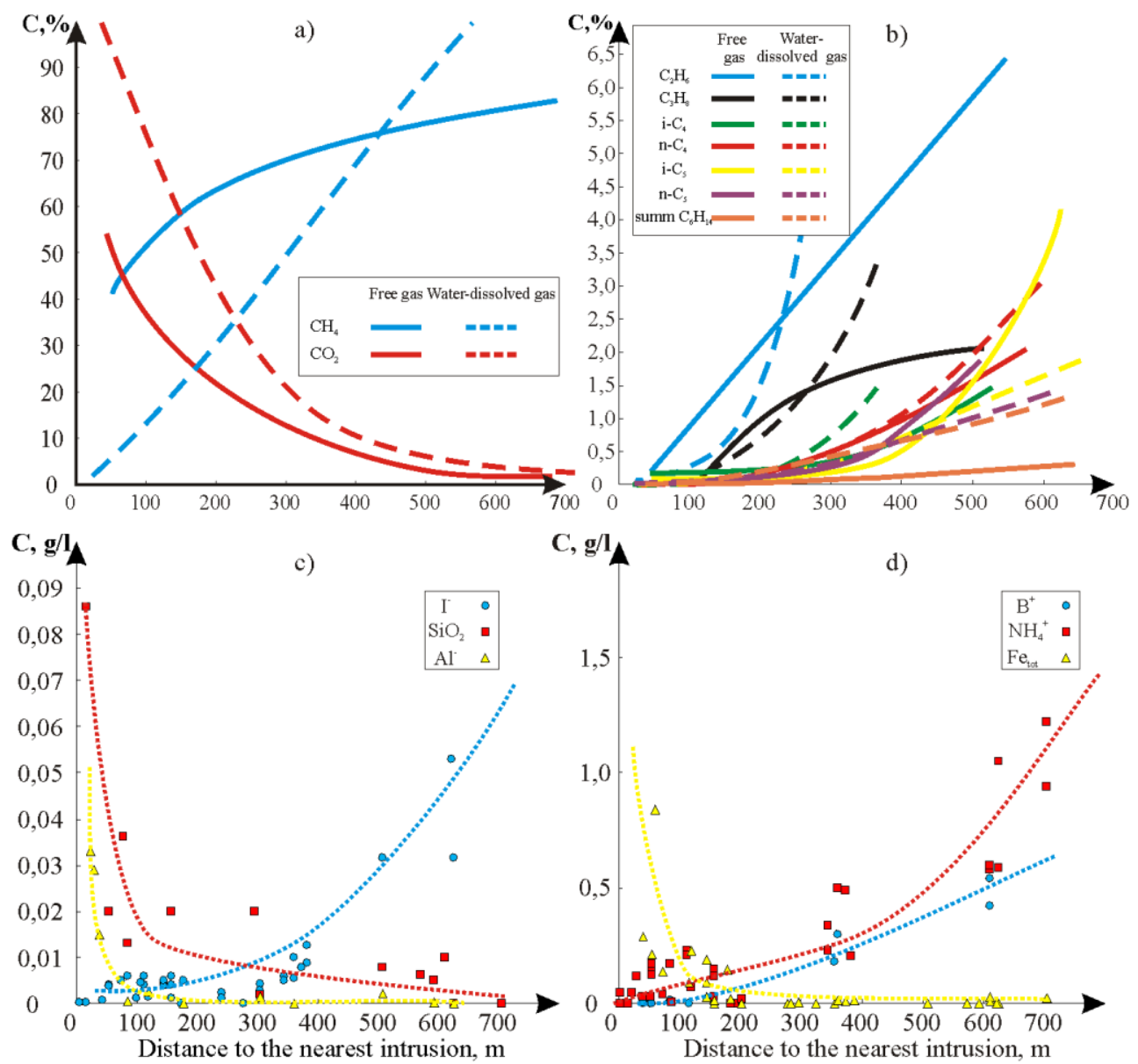

Fig. 2. Concentrations of $\mathrm{CH}_{4}$ and $\mathrm{CO}_{2}$ (a) and methane homologues (b) in the composition of free and water-dissolved gases and $\mathrm{I}^{-}, \mathrm{SiO}_{2}, \mathrm{Al}^{+}(\mathrm{c}), \mathrm{B}^{+}, \mathrm{NH}_{4}{ }^{+}, \mathrm{Fe}_{\text {total }}(\mathrm{d})$ in the composition of brines, depending on the distance to the nearest intrusive body.

The investigation of hydrogeochemical parameters revealed the following trends : the concentrations of $\mathrm{Na}^{+}, \mathrm{K}^{+}, \mathrm{Ca}^{2+}, \mathrm{Mg}^{2+}, \mathrm{Cl}^{-}$and $\mathrm{HCO}_{3}{ }^{-}$are not subjected to any significant alterations in solution; minimal concentrations of interstitial fluid $\mathrm{SO}_{4}{ }^{2-}$ were determined in the contact zone, given that the is reduced there to $\mathrm{H}_{2} \mathrm{~S}$ and has a distinctly expressed alkaline-earth barrier associated with a relatively low solubility of $\mathrm{CaSO}_{4}\left(2 \mathrm{~g} / \mathrm{dm}^{3}\right.$, in distilled water under normal conditions), and high salinity of brines (up to $400 \mathrm{~g} / \mathrm{dm}^{3}$ ). The behavior of a suite of traditional micro components $\left(\mathrm{Br}, \mathrm{SiO}_{2}, \mathrm{Sr}\right.$ and $\left.\mathrm{F}\right)$ is basically described as a direct relationship between their concentrations and the total dissolved solids. It is only concentrations of $\mathrm{NH}_{4}, \mathrm{~B}$ and I (likewise in other organic compounds) that show in increasing trend in the direction from the contact with intrusive body (Fig. 2c, d). In addition to the negative impact on the preservation of hydrocarbons in the contact zone (within 400 meters), the intrusive magmatism of traps has largely contributed to the process of hydrocarbons maturation in areas distanced from the contact. As a result of the reaction of interaction between the intruding traps and brines of the sedimentary cover, the initial composition of brines was exposed to a significant metamorphism with respect to their 
saturation with $\mathrm{Fe}, \mathrm{Al}, \mathrm{SiO}_{2}$ (Fig. 2c, d) and other components, giving thereby an evidence for a possibility of metal extraction from magmatic melts by salts into the ore-bearing fluid, which however needs further investigation in greater detail.

\section{Conclusions}

The three patterns of brines categories derived from the comprehensive analysis of the available factual material are set out below. 1) Brines revealed in Paleozoic and Proterozoic deposits of the study area have TDS from 30.2 to $469.6 \mathrm{~g} / \mathrm{dm}^{3}$, are dominantly of $\mathrm{Na} \mathrm{Cl}$, $\mathrm{Na}-\mathrm{Ca} \mathrm{Cl}, \mathrm{Ca}-\mathrm{Na} \mathrm{Cl}, \mathrm{Ca}-\mathrm{Mg} \mathrm{Cl}$ and $\mathrm{Ca} \mathrm{Cl}$ composition, with the mixed types $(\mathrm{Ca}-\mathrm{Na} \mathrm{Cl}$ and $\mathrm{Ca} \mathrm{Cl}$ ) being predominant. 2) In addition to the negative impact on the preservation of hydrocarbons in the contact zone (within 400 meters), trap magmatism has contributed to the process of hydrocarbon maturation in remote areas with respect to the contact zones. As a result of the interaction reaction between the intruding traps and brines of the sedimentary cover, the initial composition of brines experienced significant alterations due to their saturation with iron, aluminum, silica and other components, which might be beneficial for salt-induced metal extraction from magmatic melts into an ore-bearing fluid. 3) A detailed analysis of the hydrogeochemical data has provided insights allowing better understanding of the processes of oil/gas and ore formation and using this sensitive geochemical tool in assessment of the study area in the context of its prospects for hydrocarbon and ore-bearing potential.

The work was supported by the Russian Foundation for Basic Research within the scope of scientific project No 16-05-00945 and No 18-05-70074 «The Arctic Resources».

\section{References}

1 A.E. Kontorovich, A.V. Khomenko, Theoretical basis for the prediction of the oil and gas potential of sedimentary basins with intensive manifestation of trap magmatism, Geologiya i Geofizika, 42 (11-12), 1764-1773 (2001)

2 D.A. Novikov, N.S Trifonov, Hydrogeologic implications of industrial effluent disposal of the Yurubcheno-Tokhomo field (Siberian craton, Russia), Arabian Journal of Geosciences, 9 (1), 1-14 (2016)

3 D.A. Novikov, Hydrogeochemistry of the Arctic areas of Siberian petroleum basins, Petroleum Exploration and Development, 44 (5), 780-788 (2017)

4 D.A. Novikov, M.M. Saraev, Hydrogeochemistry of the Arctic areas of Siberian petroleum basins, Shiyou Kantan Yu Kaifa/Petroleum Exploration and Development, 44 (5), 737-744 (2017)

5 D.A. Novikov, A.V. Chernykh, F.F. Dultsev, Geochemistry of brines in Vendian deposits of the Siberian platform, IOP Conference Series: Earth and Environmental Science, 193 (1), 012052, 7 (2018)

6 D.A. Novikov, Genetic classification of subsurface waters and brines of Arctic regions of Siberia, IOP Conference Series: Earth and Environmental Science, 193 (1), 012049 (2018)

7 S.L. Shvartsev, The chemical composition and isotopes of strontium brines of the Tunguska basin in connection with the problem of their formation, Geochemistry, 11, 1170-1184 (2000) 